\title{
Solid-pseudopapillary tumor of pancreas in a young woman: a case report and literature review
}

\author{
SONIA OLIVEIRA LIMA ${ }^{1,2}$, VANESSA ROCHA SANTANA ${ }^{2}$, \\ SYDNEY CORREIA LEAO ${ }^{A}$, PAULO SÉRGIO FARO SANTOS ${ }^{\mathrm{a}}$, \\ RICARDO LUIS CAVALCANTI DE ALBUQUERQUE-JÚNIOR²
}

\begin{abstract}
Solid-pseudopapillary tumor of pancreas is a rare neoplasm which occurs predominantely in young females. This tumor generally is asymptomatic or minimally symptomatic and some imaging tests are useful for its diagnosis. We report a 17 years-old woman with dyspeptic symptoms submitted to an abdominal ultrasound (US), that revealed a hypoechogenic mass between the liver, right kidney and pancreas. Computer tomography (CT) scan showed a hypodense and heterogeneous mass on pancreas head. The patient underwent elective resection of the mass and the histopathology was consistent with a solid-pseudopapillary tumor of pancreas. Immunohistochemical positivity for NSE (neuron-specific enolase), progesterone receptor, alfa-1-antitrypsin, vimentin, AE1/AE3, and negativity for synaptophysin and chromogranin A confirmed the diagnosis. After four years of clinical follow-up, the patient remains in a good general condition without signs of tumor recurrence.

(Rev Med Chile 2012; 140: 1179-1184).
\end{abstract}

Key words: Pancreas; Pancreatic neoplasms; Receptors, progesterone.

\section{Tumor sólido pseudopapilar de páncreas. Presentación de un caso}

El tumor sólido pseudopapilar de páncreas es una neoplasia poco frecuente, que ocurre predominantemente en mujeres jóvenes. Este tumor generalmente es asintomático o minimamente sintomático y las imágenes son útiles para su diagnóstico. Presentamos una mujer de 17 años de edad con dispepsia que fue sometida a una ecografía abdominal que reveló una masa tumoral hipoecogénica entre el hígado, el riñón derecho y el páncreas. La tomografía computarizada mostró una masa hipodensa y heterogénea en la cabeza del páncreas. La paciente fue sometida a resección electiva de la masa y la histopatología fue consistente con el tumor sólido pseudopapilar de páncreas. La inmunohistoquímica fue positiva para NSE (enolasa neuronal específica), receptor de progesterona, alfa-1-antitripsina, vimentina, AE1/ AE3, y negativa para sinaptofisina y cromogranina A, lo que confirmó el diagnóstico. Después de cuatro años seguimiento clínico, la paciente permanece en buen estado general sin signos de recurrencia del tumor.

\author{
'Department of Medicine, \\ University Hospital, Federal \\ University of Sergipe, \\ Aracaju, SE, Brazil. \\ ${ }^{2}$ Laboratory of Morphology, \\ Science and Technology, \\ Tiradentes University, \\ Aracaju, SE, Brazil. \\ ${ }^{3}$ Laboratory of Morphology, \\ Science and Technology, \\ Tiradentes University, \\ Aracaju, SE, Brazil. \\ ${ }^{a}$ Medical Student. Medical \\ School, Federal University \\ of Sergipe, Aracaju, SE, \\ Brazil. \\ Sources of support: This \\ work had not financial \\ sponsors. \\ Recibido el 14 de octubre \\ de 2011, aceptado el 19 de \\ enero de 2012. \\ Correspondence: \\ Sonia Oliveira Lima, \\ MD, PhD. Department \\ of Medicine of Federal \\ University of Sergipe. \\ Claudio Batista Street, N/A, \\ Aracaju-SE, Brazil. P.O. \\ Box: 49060-100. \\ Cell phone number: \\ +557999829146 . \\ E-mail address: sonia.sol@ \\ ibest.com.br
}

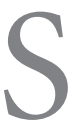
olid-pseudopapillary tumor (SPT) of pancreas is a rare neoplasm, usually characterized by a well-encapsulated mass, with low malignant potential. It occurs predominantly in young females, with a male to female ration of $1: 9.5^{1-6}$, in their third decade of life $\mathrm{e}^{1,2,7-11}$. Histogenesis remains a debatable question: acinar, endocrine, ductal and progenitor cells have been postulated as possible beginnings of this tumor ${ }^{12}$. 
Although this tumor can reach large size, with a mean of $10 \mathrm{~cm}$ at diagnosis, it is frequently asymptomatic or minimally symptomatic ${ }^{5,6,8,10,13}$. Due to the large size, sometimes this tumor promotes a bulge in the abdominal wall ${ }^{10,14}$.

Solid-pseudopapillary tumor of pancreas can be visualized in many imaging modalities, such as ultrasonography (US), X-ray computed tomography (CT) and magnetic resonance imaging, which can be used to differentiate it from other pancreatic lesions s, $^{1,2,415-18}$.

Complete resection is curative in most cases $^{9,15,19}$, but prognostic factors are not well established and clinical evolution cannot be predicted. Rare cases of fatal metastasizing solid-pseudopapillary tumors of pancreas have been previously reported, suggesting that these tumors may occasionally show aggressive clinical behavior $^{2,9,14,20}$. In this article, we present a case of a SPT in a 17-year-old Brazilian woman with a good evolution.

\section{Case report}

A 17-year-old girl complaining of dyspeptic symptoms and right upper quadrant pain for several months was admitted to our ambulatory for further evaluation. She had no history of abdominal trauma, surgery, drug usage or smoking. Clinical examination found a palpable mass in the right upper quadrant with associated postprandial overloading. Laboratory findings showed no abnormalities.

An abdominopelvic US revealed a heterogeneous hypoechogenic solid mass lesion measuring $10.1 \times 9.1 \times 9.0 \mathrm{~cm}$ at the underlying hepatic border, right kidney and head of pancreas. CT scan showed a round shaped well-marginated, hypodense and heterogeneous mass at the pancreatic head. After intravenous iodine contrast agent administration, the lesion showed minimally heterogeneous contrast enhancement markedly less than the normal pancreatic tissue (measuring $9 \times 8 \mathrm{~cm}$ ) (Figure 1A).The patient underwent elective resection of the abdominal mass (Figures 2A and 2B). The resected specimen was fixed in $10 \%$ formalin and submitted for pathological analysis.

Gross examination revealed a round partially cystic mass, formed by a brownish, soft and friable tissue. Microscopically, the solid areas consisted of uniform polyedral eosinophilic cells arranged around delicate fibrovascular stalks. Degeneration of cells away from the vessels impinge a pseudopapillary pattern, somewhat reminiscent of ependymal rosettes (Figure 2C). The neoplastic tissue showed large cystic areas with extensive hemorrhage and necrosis. Also, cholesterol clefts and foreign body giant cell reaction could be noticed. Vascular invasion by neoplastic cells was observed focally. Prominent nuclear pleomorphism or atypia, high mitotic rate and areas of diffuse growth pattern were not detected. In immunohistochemistry, antibodies markers were positive to NSE (neuron-specific enolase), progesterone receptor, alfa-1-antitrypsin, vimentin, AE1/AE3, and negative to synaptophysin e chromogranin A.

The patient developed well in the postoperative period, with normal US (three, 12 and 24 and 48 months) and CT scans (12, 24 and 48 months) and no evidence of residual disease (Figure 1B).

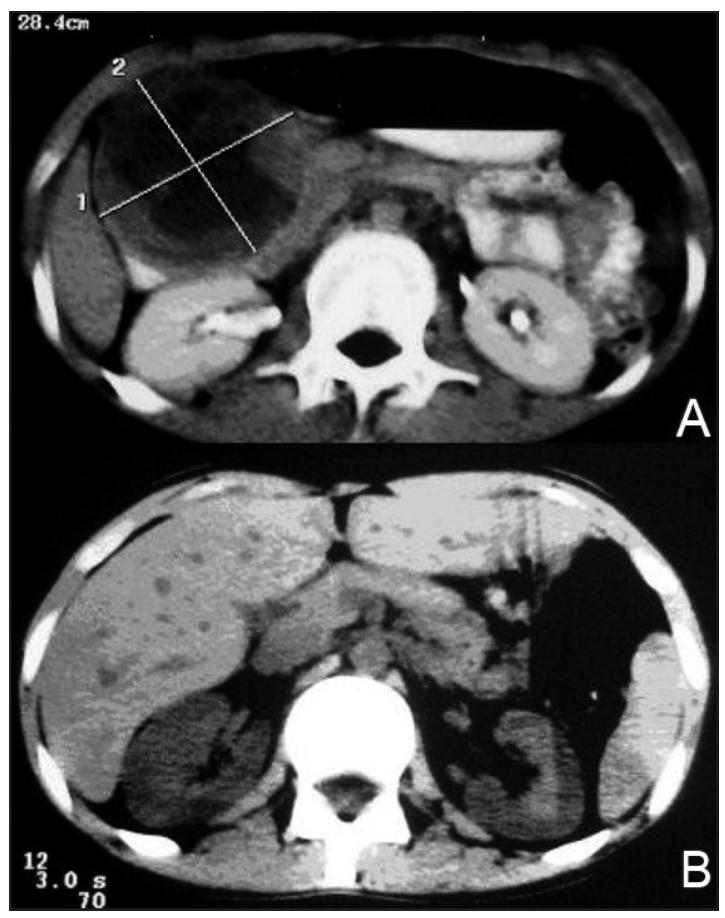

Figure 1. $A$ and $B$ : $C T$ photos. A: Preoperative $C T$. A round shaped, well-marginated, hypodense and heterogeneous mass is found at the pancreatic head; B: A normal CT 48 months later shows no evidence of residual disease. 

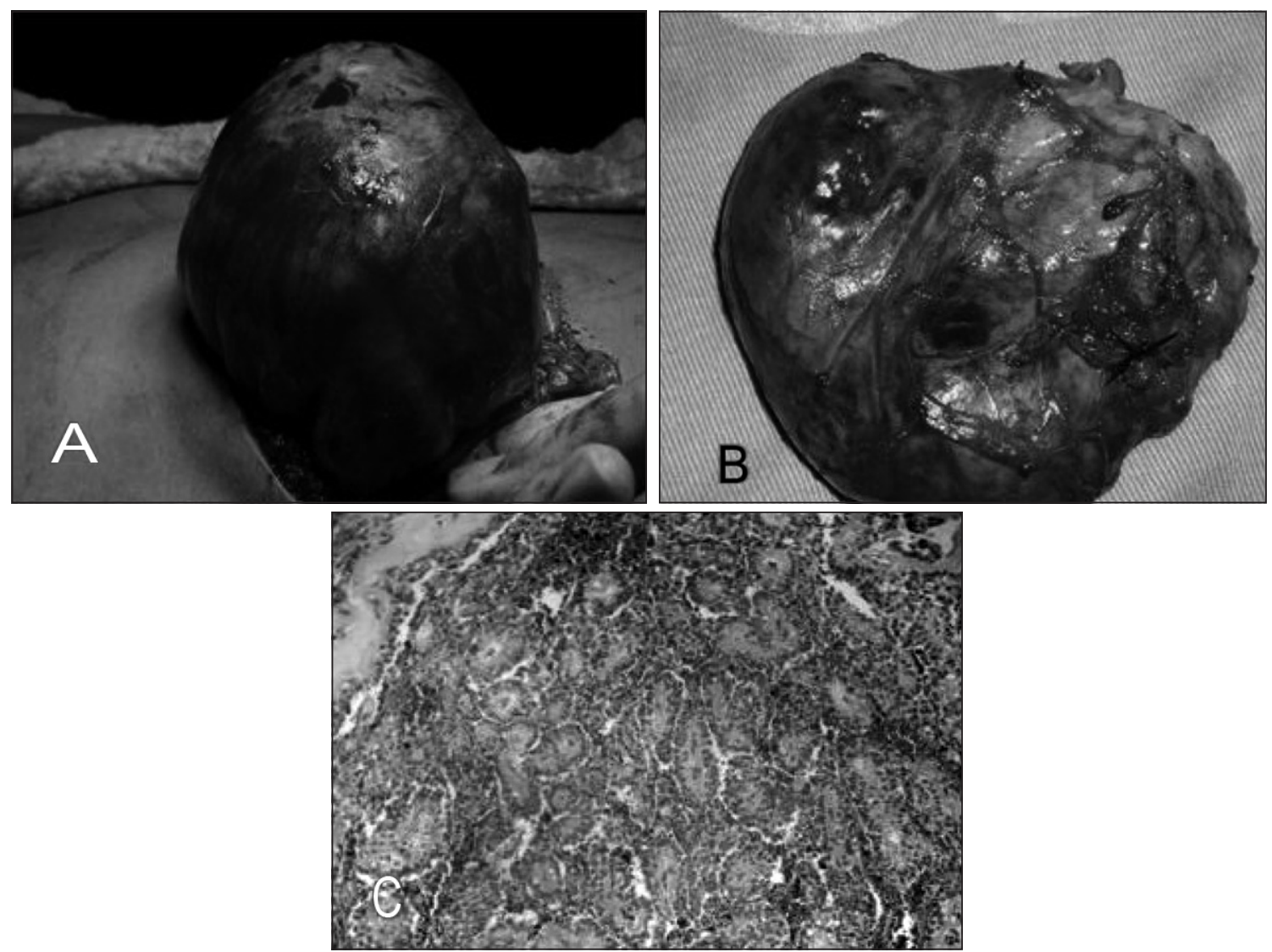

Figure 2. A and B: Macroscopic photos. C: Histological photomicrography. A: A large mass replaces totally the pancreatic head; B: Gross image of pancreatic tumor. Cut surface was cystic and partially necrotic; C: Pseudopapillary pattern of neoplastic cells around vessels. (HE, 100x).

\section{Discussion}

Solid pseudopapillary tumor (SPT) of the pancreas is rare (1-6\% of exocrine pancreatic tumors at most institutions) $)^{1,2,9,11,15,19}$. This tumor was first described by Frantz in 1959 as a "papillary tumor of the pancreas, benign or malignant" 21 . Since then, several names have been used to describe this rare lesion, such as solid and cystic tumor of the pancreas, papillary-cystic tumor, solid and papillary epithelial neoplasm and Frantz tumor ${ }^{2,7,8,10}$. In 1996, the World Health Organization (WHO) renamed this tumor as SPT for the international histologic classification of tumor of the exocrine pancreas and this nomenclature was also adopted in the recent edition ${ }^{22,23}$.

Since the report of five cases by Kloppel et al. ${ }^{24}$ in 1981, the number of reported cases has increa- sed. According to Lam et al. (1999), a total of 452 cases have been reported in the English literature and Yu et al. (2010) found 553 patients with SPT in China, from 1996 to $2009^{11,25}$.

This uncommon tumor is found mainly in young non-Caucasian women between the 2nd and 3 rd decades of life $1,2,8,9,11,26,27$. It seems to have a predilection for Asian and African-American women, although rare cases have been reported in children and men ${ }^{2,4,27}$. Our patient is a 17-year-old woman in according to literature.

Patients with SPT of the pancreas are often clinically asymptomatic ${ }^{8,11,26}$. They may present with a gradually enlarging abdominal mass or complain of vague abdominal pain or discomfort ${ }^{8,9,11,26,27}$. The abdomen is usually nontender on palpation, but obstructive symptoms may occur if the tumor grows large enough to compress adjacent visce- 
$\mathrm{ra}^{11,17}$. In this case, she had a large abdominal mass, vague abdominal pain and dyspeptic symptoms.

These tumors present at the imaging exams as cyst of great dimensions when compared with other pancreatic tumors ${ }^{11,16,17,26,28}$. Frequently there is an incorrect preoperative diagnosis, being confused with pancreatic pseudocyst or intraabdominal cyst ${ }^{13,17,18,20,27}$. In the present report the US was non specific and showed a mass image that could be primarily hepatic, pancreatic or placed in the wall of intestinal loop. CT scan showed a round shaped, hypodense and heterogeneous mass at the pancreatic head and surgical procedure confirmed tumor topography.

Complete surgical resection including the pancreatic mass and also any neoplastic extension to adjacent organs, in case it exists, is considered the gold standard therapy ${ }^{7,8,9,11,17,27-30}$. More aggressive lesions, characterized by local invasion, recurrence or metastasis at the bounded distance can also have the same therapeutic approach ${ }^{7,11,27}$. In our case the pancreatic tumor was completely resected with a tiny but free surgical margin (smaller margin measured $2 \mathrm{~mm}$ in length). There is no evidence of tumor recurrence so far, suggesting that provided treatment was adequate in this case.

SPT of the pancreas has distinctive pathologic features. The mass may occur anywhere in the pancreas but is most frequently found in the head or tail ${ }^{8,11,17,27}$. At gross examination, the mass is usually large (mean maximum dimension, $9.3 \mathrm{~cm}$ ), well demarcated from pancreatic parenchyma and contains varying amounts of necrosis, hemorrhage and cystic change $e^{4,8,9,26,27,30}$. Our patient had a well-circumscribed, round, brown-purple colored tumor located in the pancreatic head, sizing about $9.0 \times 8.0 \mathrm{~cm}$.

At histology, this case showed a very typical appearance of uniform neoplastic cells arranged around small vessels in a manner similar to papillary structures, the so called "pseudopapillary pattern". In solid areas cells were more compact but still separated by vessels with a hyalinized stroma. There were large areas of hemorrhage and necrosis leading to cystification, a common feature in this type of tumor, as well as foreign body reaction around cholesterol clefts. Neoplastic cells disclosed ovoid or round nuclei, with finely dispersed chromatin, some with a peculiar indentation or groove. There was no nuclear pleomorphism and mitotic activity was very low.
Focally, we observed vascular invasion by neoplastic cells, a feature described by some authors as indicative of aggressive behavior ${ }^{9,13,14,17,27}$. Nevertheless, other criteria of malignancy as perineural invasion, extensive invasion into surrounding tissue, nuclear atypia, high mitotic index and diffuse growth pattern with spindle or sarcomatoid cells were not present in this case. As a matter of fact, until now, there are no histopathological criteria reliable to predict prognosis of a SPT. Although most of these tumors have a benign behavior and good prognosis, there is a consensus to classify these neoplasms as lesions of uncertain malignant potential or low malignant potential $^{11,13,17}$.

SPTs are typically positive for $\alpha 1$-antitrypsin, 1 -antichymotrypsin, neuron-specific enolase, vimentin and progesterone receptor when submitted for immunohistochemical studies. Cytokeratins are very rarely expressed. Also, SPTs are usually negative for chromogranin and hormone peptides $^{8,9,11,16,17,26}$. Immunohistochemistry can be a useful tool in difficult cases, especially to differentiate SPTs from endocrine pancreatic tumors. Positivity for chromogranin and negativity for 1-antitrypsin, 1-antichymotrypsin and progesterone receptor in this type of tumor are very typical. In this case, antibodies markers were positive to NSE (neuronspecific enolase), progesterone receptor, alpha-1antitrypsin, Vimentin, AE1/AE3, and negative to synaptophysin and chromogranin A.

\section{Conclusion}

We describe a case of a solid-pseudopapillary tumor of pancreas in a young female, which was presented as a large cystic mass in pancreatic head. Complete surgical resection was achieved and patient developed well in the postoperative period. Besides large tumor weight and vascular invasion by neoplastic cells observed in histopathological analysis, which could indicate an aggressive behavior, the patient has no evidence of recurrent disease after four years of follow-up.

\section{References}

1. Aretxabala X, Roa I, León J, Maluenda F. Tumores quísticos del páncreas. Rev Med Chile 2008; 136: 1188-96. 
2. Cienfuegos JA, Lozano MD, Rotellar F, Martí P, Pedano $\mathrm{N}$, Arredondo J. et al. Solid pseudopapillary tumor of the pancreas (SPPT). Still an unsolved enigma. Rev Esp Enferm Dig 2010; 102: 722-8.

3. Venturelli FM, Carrasco CL, Del Pozo ML, Cárcamo CI, Felmer OE, Ibaceta MC, et al. Solid-pseudopapillary tumor of the pancreas. Presentation of 3 clinical cases. Rev Gastroenterol Peru 2011; 31 (1): 72-6.

4. Choi JY, Kim MJ, Kim JH, Kim SH, Lim JS, Oh YT, et al. Solid pseudopapillary tumor of the pancreas: typical and atypical manifestations. AJR 2006; 187: W178-86.

5. Coleman KM, Doherty MC, Bigler SA. Solid-pseudopapillary tumor of the pancreas. Radiographics 2003; 36: 1644-8.

6. Sakagami J, Kataoka K, Sogame Y, Taii A, Ojima T, Kanemitsu D, et al. Solid pseudopapillary tumor as a possible cause of acute pancreatitis. JOP 2004; 5: 348-52.

7. Camacho-Aguilera JF, Romero-Mejía C, ValenzuelaEspinoza A. Solid pseudopapillary tumor of the pancreas: case report and literature review. Cir Ciruj 2010; 78: 67-72.

8. Chen S, Zou S, Dai Q, Li H. Clinical analysis of solidpseudopapillary tumor of the pancreas: report of 15 cases. Hepatobiliary Pancreat Dis Int 2008; 7: 196200.

9. De Castro SMM, Singhal D, Aronson DC, Busch ORC, van Gulik TM, Obertop H, et al. Management of solidpseudopapillary neoplasms of the pancreas: a comparison with standard pancreatic neoplasms. World J Surg 2007; 31: 1129-34.

10. Eder F, Schulz H, Röcken C, Lippert H. Solid-pseudopapillary tumor of the pancreatic tail. World J Gastroenterol 2005; 11 (26): 4117-9.

11. Yu PF, Hu ZH, Wang XB, Guo JM, Cheng XD, Zhang YL, et al. Solid pseudopapillary tumor of the pancreas- A review of 553 cases in Chinese literature. World J Gastroenterol 2010; 16 (10): 1209-14.

12. Geers C, Moulin P, Gigot JF, Weynand B, Deprez P, Rahier J, et al. Solid and Pseudopapillary tumor of the pancreas-Review and new insights into pathogenesis. Am J Surg Pathol 2006; 30: 1243-9.

13. Meshikhes AW, Atassi R. Pancreatic pseudopapillary tumor in a male child. JOP 2004; 5: 505-11.

14. Abraham SC, Klimstra DS, Wilentz RE, Yeo CJ, Conlon $\mathrm{K}$, Brennan M, et al. Solid-pseudopapillary tumors of the pancreas are genetically distinct from pancreatic ductal adenocarcinomas and almost always harbor bcatenin mutations. American Journal of Pathology 2002; 160 (4): 1362-9.

15. Francis WP, Goldenberg E, Adsay NV, Steffes CP, Webber JD. Solid-pseudopapillary tumors of the pancreas: case report and literature review. Current Surgery 2006; 63 (6): 469-72.

16. Salla C, Chatzipantelis P, Konstantinou P, Karoumpalis I, Pantazopoulou A, Dappola V. Endoscopic ultrasoundguided fine-needle aspiration cytology diagnosis of solid pseudopapillary tumor of the pancreas: A case report and literature review. World J Gastroenterol 2007; 13 (38): 5158-63.

17. Vargas-Serrano B, Domínguez-Ferreras E, ChinchónEspino D. Four cases of solid pseudopapillary tumors of pancreas: Imaging findings and pathological correlations. European Journal of Radiology 2006; 58: 132-9.

18. Xiuzhong Y, Yuan J, Mengsu Z, Shengxiang R, Bo Y. Solid pseudopapillary tumor of the pancreas: cross-sectional imaging and pathologic correlation. Pancreas 2010; 39 (4): 486-91.

19. Bostanoglu S, Otan E, Akturan S, Hamamci EO, Bostanoglu A, Gokce A, et al. Frantz's tumor (solid pseudopapillary tumor) of the pancreas. A case report. JOP. J Pancreas 2009; 10 (2): 209-11.

20. Snoeckx A, Bernard P, Vanhoenacker FM, Brouwers J. Solid pseudopapillary tumor of pancreatic tail. JBR-BTR 2008, 91: 112-3.

21. Frantz VK. Tumors of the pancreas. Atlas of tumor pathology: fasc 27-28, ser 7. Washington, DC: Armed Forces Institute of Pathology, 1959; 32-33.

22. Kloppel G. Solid-pseudopapillary neoplasm. In: Hamilton, Sr \& Aaltonen, LA. WHO Classification of TumoursPathology and Genetics Tumours of the Digestive System. IARC Press, Lyon, 2000, p.246-248.

23. Kloppel G, Solcia E, Longnecker DS, Capella C, Sobin LH. World Health Organization: institutional histological classification of tumours-histological typing of tumours of the exocrine pancreas 2nd ed. Berlin, Germany: SpringerVerlag, 1996.

24. Kloppel G, Morohoshi T, John HD, Oehmichen W, Opitz $\mathrm{K}$, Angelkort A, et al. Solid and cystic acinar cell tumor of the pancreas: a tumor in young women with favourable prognosis. Virchows Arch A Pathol Anat Histol 1981; 392: 171-83.

25. Lam KY, Lo CY, Fan ST. Pancreatic solid-cystic-papillary tumor: clinicopathologic features in eight patients from Hong Kong and review of the literature. World J Surg 1999; 23: 1045-50.

26. Chen S, Zou S, Dai Q, Huang P, Cai W, Li H. The clinicopathological and immuohistochemical analysis of solid-pseudopapillary tumor of the pancreas: report of 9 case. Journal of Nanjing Medical University 2007; 21 (6): 398-401.

27. Choi SH, Kim SM, Oh JT, Park JY, Seo JM, Lee SK. Solid 
pseudopapillary tumor of the pancreas- a multicenter study of 23 pediatric cases. Journal of Pediatric Surgery 2006; 41: 1992-95.

28. Costa SRP, Henriques AC, Godinho CA, Miotto MJ, Costas MC, Horta SH, et al. Tumor papilar sólido-cístico do pâncreas: aspectos clínico-radiológicos e resultados cirúrgicos em cinco pacientes operados. Einstein. 2007; 5 (2): 161-5.
29. Costa-Neto GD, Amico EC, Costa GID. Tumor sólidocístico pseudopapilar do pâncreas (tumor de Frantz). Estudo de quatro casos. Arq Gastroenterol 2004; 41 (4): 259-62.

30. Frago R, Fabregat J, Jorba R, García-Borobia F, Altet J, Serrano MT, et al. Solid pseudopapillary tumors of the pancreas: diagnosis and curative treatment. Rev Esp Enferm Dig (Madrid) 2006; 98 (11): 809-16. 